\title{
Dissolved organic matter in hand-dug well water as groundwater quality indicator: assessment using laser-induced fluorescence spectroscopy and multivariate statistical techniques
}

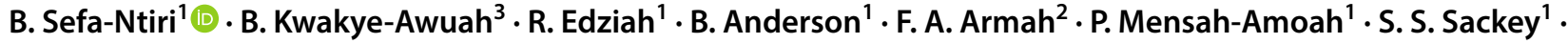

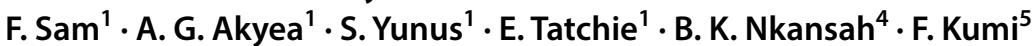

Received: 14 November 2019 / Accepted: 6 March 2020 / Published online: 7 April 2020

C) Springer Nature Switzerland AG 2020

\begin{abstract}
In groundwater, dissolved organic matter (DOM), a complex material, is a contaminant of concern owing to its ability to influence water quality and stimulate microbial metabolism. Using a 445-nm diode laser-induced fluorescence (LIF) spectroscopy, DOM contamination levels have been investigated of well water samples fetched from ten privately owned hand-dug wells during dry and wet seasons of 2016, 2017 and 2018, in Ghana. The results showed spatio-temporal heterogeneities in the LIF spectra, and the fluorescence intensity peaks were generally higher and broader during the wet season than the dry season. In this study, DOM fluorescence spectra at an emission wavelength band of 460-650 nm showed two distinct broad peak shoulders within 480-500 nm and 550-570 nm, engulfing the water Raman peak at $527 \pm 2 \mathrm{~nm}$ for all the water samples studied. Furthermore, principal component analysis and cluster analysis were used to differentiate the 2016 water samples based on their DOM contamination levels. In each case, three groups or clusters were identified based on their similarities and dissimilarities. The study revealed humic DOM substances as the most typical well water fluorophores. Applying the K-nearest neighbour algorithm as a classifier method for the classification of 30 water samples studied in 2016, 16.7\% (5/30) were classified as very good drinking water, $46.7 \%(14 / 30)$ as good, $26.7 \%(8 / 30)$ as fairly good, and $10 \%(3 / 30)$ as bad drinking water samples. In general, levels of dissolved organic matter contamination increased over the study period during the rainy seasons for wells situated in close proximity to septic tanks, refuse dumps, public toilets and in wetlands. Thus, in the study the fluorescence intensity depends on the sampling site and the season, and indicates the DOM contamination level.
\end{abstract}

Keywords Dissolved organic matter · Hand-dug well water - Laser-induced fluorescence - Dry and wet seasons . Multivariate statistical techniques - Water quality monitoring and assessment

\section{Introduction}

Most of the available freshwater on Earth is locked up in the ground [47]. For this reason, groundwater constitutes the main resource in terms of obtainable quantities for water supply. Globally, in excess of two billion people depend on groundwater for their day-to-day water use $[41,47]$. In both the global north and south, groundwater bodies are the most vital and safest source of drinking water $[3,32,47]$. Groundwater sources are very important

B. Sefa-Ntiri, bsefa-ntiri@ucc.edu.gh | 'Department of Physics, School of Physical Sciences, College of Agriculture and Natural Sciences, University of Cape Coast, Cape Coast, Ghana. ${ }^{2}$ Department of Environmental Science, School of Biological Sciences, College of Agriculture and Natural Sciences, University of Cape Coast, Cape Coast, Ghana. ${ }^{3}$ Department of Physics, Kwame Nkrumah University of Science and Technology, Kumasi, Ghana. ${ }^{4}$ Department of Statistics, School of Physical Sciences, College of Agriculture and Natural Sciences, University of Cape Coast, Cape Coast, Ghana. ${ }^{5}$ Department of Agricultural Engineering, School of Agriculture, College of Agriculture and Natural Sciences, University of Cape Coast, Cape Coast, Ghana. 
resource for drinking purpose because it has been found to contain over $90 \%$ of the fresh water recharge over the world. Therefore, there is always the need to study groundwater quality since groundwater is difficult and expensive to restore once polluted by a variety of contaminants, both inorganic and organic [28].

The utilization of groundwater is expected to increase as a result of climate change and increasing global water demand, which basically is due to economic expansion, population growth and urbanization. In Ghana, and many developing nations, groundwater constitutes the drinking water of choice owing to the pollution of surface water systems by gold mining activities [4, 5], livestock and climate effect.

On the whole, human pressure on groundwater becomes stronger if we consider those areas in which urban, industrial and agricultural settlements are particularly developed, such as the alluvial and coastal plains [47]. According to the World Health Organisation [61], throughout the world, more than 150 million inhabitants are below the altitude of $1 \mathrm{~m}$ above sea level (a.s.l.) and 250 million live below the altitude of $5 \mathrm{~m}$ a.s.l. Owing to this, these areas are commonly concerned with the deterioration of the environmental system and, in particular, of their water resources.

Dissolved organic matter (DOM) is a composition of humic-like and fulvic-like materials and amino acids, proteins and peptides that may be found in a groundwater body. Therefore, effects of DOM on water quality are multifaceted. DOM in water influences drinking water quality (for example, odour, colour and taste), reduces water treatment efficiency $([46,59]$ and intensifies microbial metabolism $[52,58]$; it could be new or old, ubiquitous, labile and of variable structure and composition with character normally influenced by a number of factors including space and time effects $[6,13,23,52,58]$; it is a significant means of transportation of nutrients which may be inside or outside of an aquatic system [22,25], and can interact with many organic or inorganic contaminants, such as pesticides and polycyclic aromatic hydrocarbons (PAHs) and heavy metals [21, 25]. Accordingly, the varied composition of DOM is dependent on the origin of the source material (e.g. wetlands, plants, soils, algae, refuse dump and human excreta). Thus, DOM includes a broad range of organic molecules of various sizes and composition that are released by all living and dead plants and animals [25, 45].

A plethora of independent techniques including chemical, spectroscopic and isotopic analyses have been used to characterize DOM in various ecosystems across the world $[22,34]$. Fluorescence spectroscopy, an alternative technique, has been used to assess indications and proportions of levels of DOM contaminants in water systems. Water of all kinds fluoresces [9], because only absorbing molecules can emit fluorescence. Carstea et al. [12] have posited that fluorescence spectroscopy an inexpensive, reliable, excellent technique and fast monitoring tool is used to detect and quantify contaminants in a short time, for quick mitigation of pollution sources and site remediation, and for characterization of natural dissolved organic matter. In other words, fluorescence spectroscopy has proven to be an excellent technique in quantifying aquatic DOM, from autochthonous, allochthonous, or anthropogenic sources [38].

In this field, laser-induced fluorescence (LIF) is a relatively inexpensive and useful technique for environmental monitoring and has been applied in the investigation of quantity, origin, character, and degradation of DOM, and such as to provide information (e.g. amount of humic and fulvic acids, protein-like material and phytoplanktonderived material) about the various sources in a range of aquatic environments $[6,13,57,66,67]$. For this reason, measuring the fraction of DOM that absorbs light at specific wavelengths, and subsequently releasing it at longer wavelengths (i.e. fluorescence) is diagnostic of DOM type and amount. Dissolved organic matter, such as humic and fulvic acids, have a particularly strong preference for blue, violet and ultraviolet light. Hence, various excitation light sources (e.g. lamps, LEDs, lasers) have been employed in the study of DOM contaminants in water samples. For example, lasers and LEDs have been used for disinfection in water $[2,15,17,43]$, while induced fluorescence using these same sources has been used to estimate water pollution and probe the composition of DOM in watersheds [51]. Saraceno et al. [45] have used excitation and emission at $370 \mathrm{~nm}$ and $460 \mathrm{~nm}$, respectively, to quantify the fluorescent fraction of the coloured DOM (referred to as CDOM fluorescence or FDOM). Due to its versatility, diode lasers have been used extensively in environmental monitoring of trace gases [11]. A diode laser is a semiconductor device similar to an LED. Diode lasers impress by their high efficiency, their low running costs, compactness, high spectra purity, small sizes and low input power $[48,53]$. Compared to most lasers, diode lasers are low cost because of existing semiconductor technology and they are typically run on small batteries. In addition, research has shown that blue light fluorescence $\left(\lambda_{\text {emission }}=430-500 \mathrm{~nm}\right)$ can be a good proxy for DOC, in environments with terrestrial inputs. However, limited studies of using blue light fluorescence as excitation light source for the monitoring of DOM contaminants in natural waters, like hand-dug well water, have not been frequently reported.

To this end, the specific objective of this study was to use a 445-nm diode laser excitation to detect DOM contamination levels under spatial and temporal conditions in some selected hand-dug well water systems located 
at possible DOM sources. The water samples used in this study have been classified using tools such as principal component analysis (PCA), cluster analysis (CA) and $\mathrm{K}$-nearest neighbour (K-NN) algorithm. In addition to the results of the assessment of water quality investigations carried out in this study on DOM concentration levels, microbial and faecal indicators and certain physicochemical parameters were initially determined which in totality call for regular monitoring of the drinking water quality standards for hand-dug well water systems. To the best of the knowledge of the authors, for the first time, groundwater quality assessment has been tied together with DOM fluorescence, K-NN and other statistical analyses as a potential diagnostic tool for effective monitoring, assessment and classification of DOM contamination levels in well water resources.

\section{Materials and methods}

\subsection{Study area}

This study was conducted in a community located in the Cape Coast metropolis near the University of Cape Coast, Ghana. The community, Amamoma, lies between longitude $1^{\circ} 17^{\prime} 41^{\prime \prime}$ East and latitude $5^{\circ} 6^{\prime} 40^{\prime \prime}$ North of Cape Coast. The area is a low-lying wetland plain (Fig. 1) with minor streams ending in wetlands that annually experience flood waters in the major rainy season (April to July). Thus, the study area is characterized by defined wet and dry seasons. It has an average monthly relative humidity between 85 and $99 \%$. Most of the precipitation occurs from May to July with an average annual rainfall of $1295 \mathrm{~mm}$. During this period, flooding is normal and common for groundwater and surface water recharge. Groundwater-surface water exchange with the underlying aquifer is possible, especially during the dry season when the water head is low [40].

\subsection{Geology and soil}

The study area is categorized under the series of Cape Coast granitoids which contain well foliated, often magmatic, potash-rich granitoids that come in the form of muscovite-biotite, granite and granodiorite. Usually, lithologies include quartz diorites, tonalities and trondhjemites, granodiorites, adamellites and granites. The hills are generally overlaid by sandy and clayey silts, while the valleys are covered by clayey gravel with lateritic soils exposed in a number of areas $[18,37]$.

\subsection{Water sampling: locations, collections and analysis}

Groundwater samples were collected from ten privateowned hand-dug wells in the study area. The general

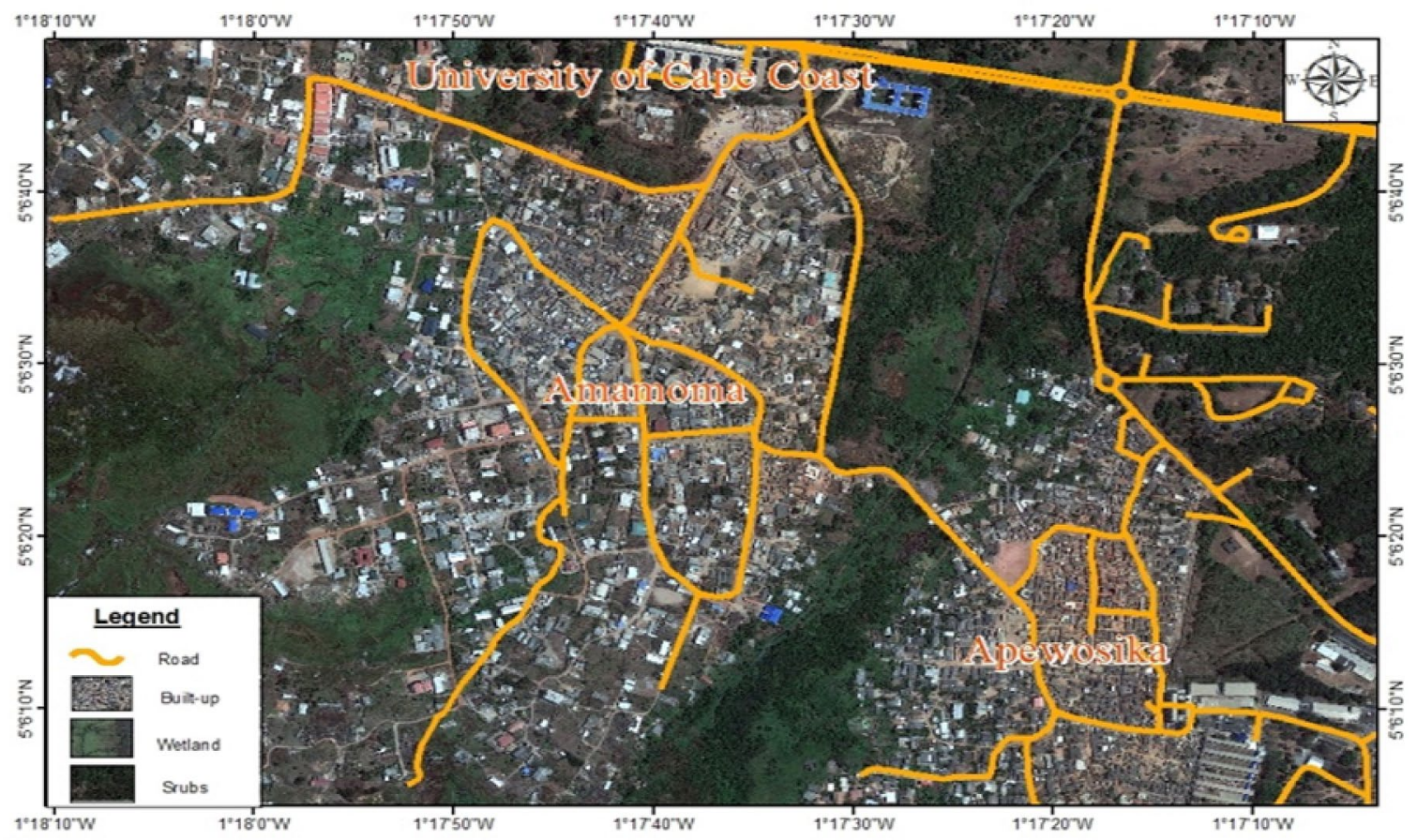

Fig. 1 Satellite map of the study area 
description of the wells studied indicates well age, well depth (ranged from 300 to $550 \mathrm{~cm}$ ) obtained from their owners or the information inscribed on them, and proximity to different known DOM pollution sources (Table 1).

The basic simple random sampling technique was used to select the hand-dug wells for the water samples for the study. The selection yielded samples that were representative of the different natural environments (wetland, semi-arid and arid lands) in the study area (Fig. 2). A Global Positioning System (GPS) was used to mark the hand-dug wells with their designated names: wA to $W J$ in alphabetical order. In all, three batches of fetching trips were made from each of the ten wells in each month of February, March and April of 2016, 2017 and 2018, respectively. At the well sites, a multipurpose water quality checker (U-50 series, Horiba) was used to measure some characteristic parameters including the $\mathrm{pH}$, salinity and temperature of the samples (Table 2 ). All analyses were done in duplicates and the average calculated value recorded (Table 2). During each fetching trip, water samples were fetched into pre-cleaned opaque plastic bottles kept in an air-tight dark polythene bags conveyed to a temperature-controlled laboratory within $2 \mathrm{~h}$ for analyses. In all, there were no appreciable changes in the values measured at well site and in the laboratory. Salinity was mostly less than $1 \mathrm{ppt}$, indicating that saltwater intrusion was non-existent. However, the water samples were slightly more acidic (more than WHO standard for drinking water) during the dry season than the wet season (Table 2).

It is well known that hand-dug wells are vulnerable to contamination and as such pose a significant public health threat to those who rely on them for domestic water use $[1,33]$. It is always very difficult to protect hand-dug well from contamination. For example, there are many ways for surface water to leach in, and using bucket on a rope to fetch water easily transfers bacteria to the groundwater. In this study, different bacteria species were detected during the rainy season of April 2016 (Table 3) to support the assertion that in many cases DOM in a water body will also be accompanied by an active microbial community [38]. Thus, DOM in hand-dug well water could act as reservoir of pathogenic bacteria and exhibit potential health hazards from faecal contaminants with the amount of faecal indicator bacteria, such as Escherichia coli and Streptococcus spp. (Table 3).

\subsection{Laser-induced fluorescence spectroscopic measurement}

The LIF measurements were taken with a set-up similar to the laboratory bench-top LED-IF/LIF set-up described elsewhere by Sharikova and Killinger [50]. The schematic of the set-up (Fig. 3) for the LIF measurement consists of an excitation source, a sample holder and a detection unit.

A continuous-wave (cw) diode laser used in our system has the wavelength of $445 \mathrm{~nm}$ and an average output power of $100 \mathrm{~mW}$. A similar diode laser has been employed in remote sensing study of water quality assessment by Brydegaard et al. [10]. In this study, the laser output was incident on the water sample contained in a quartz cuvette of optical path length of $10 \mathrm{~mm}$. The emitted light was collimated by a converging lens (focal length $=5 \mathrm{~cm}$ ) placed at $10 \mathrm{~cm}$ from the sample and passed through an optical fibre mounted at right-angle to the path of the laser beam. This sample illumination geometry is commonly used for LIF studies, and it allows the cuvette to be illuminated at the centre which was

Table 1 General description of the hand-dug wells sampled in the study: designated well name, type of its environment, depth, age and the possible source (s) of DOM

\begin{tabular}{|c|c|c|c|c|}
\hline Well sample & Well environment & $\begin{array}{l}\text { Well depth }(\mathrm{cm}) \\
\text { [diameter }(\mathrm{cm})]\end{array}$ & $\begin{array}{l}\text { Well age } \\
\text { (years) }\end{array}$ & Possible source(s) of DOM \\
\hline wA & Semi-wetland, clayey/sandy soil, covered & $362[110]$ & 10 & Septic tank; wetland; soil \\
\hline$w B$ & Semi-wetland, clayey/sandy soil, covered & $542[113]$ & 11 & Old refuse dump; soil \\
\hline$w C$ & Wetland, clayey/sandy soil, covered & $460[106]$ & 11 & Septic tank; wetland; soil \\
\hline$w D$ & Semi-wetland, clayey/sandy soil, covered & $430[105]$ & 12 & Wetland; public toilet; soil \\
\hline$w E$ & Wetland, clayey/sandy soil, not covered & $500[110]$ & 10 & Septic tank; wetland; soil \\
\hline$w F$ & Wetland, clayey/sandy soil, covered & $328[102]$ & 7 & Septic tank; wetland; soil \\
\hline wG & Semi-wetland, clayey/sandy soil, partially covered & $320[105]$ & 10 & Wetland; soil \\
\hline wH & Semi-wetland, clayey/sandy soil, covered & $300[118]$ & 9 & Wetland; soil \\
\hline wl & Arid, clayey/sandy soil, covered & $555[115]$ & 3 & Soil \\
\hline wJ & Semi-wetland, clayey/sandy soil, covered & 315 [112] & 8 & Wetland; soil \\
\hline
\end{tabular}




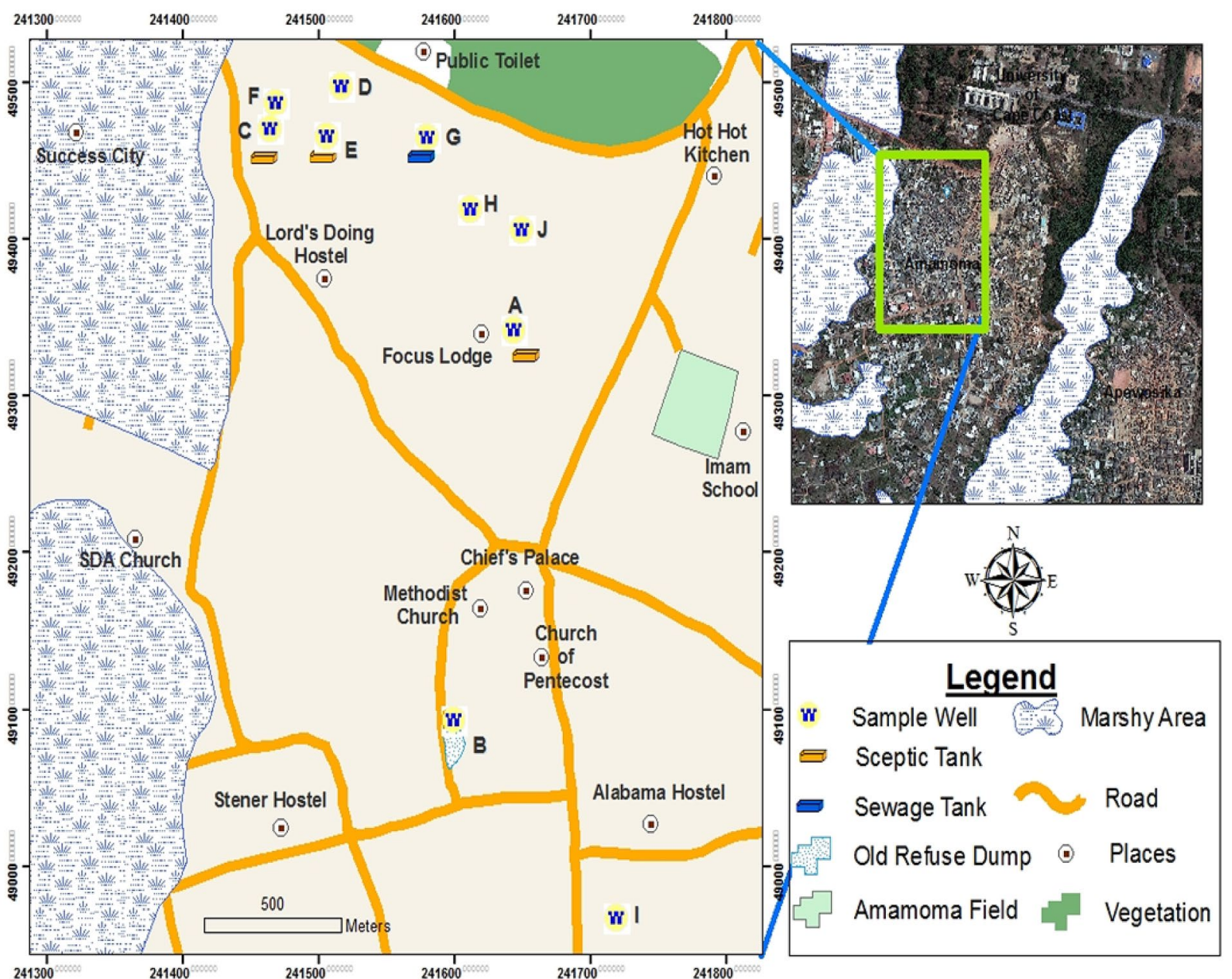

Fig. 2 Study area map showing the sites/locations where the ten (10) wells were sampled

Table 2 Characteristic parameters of water samples fetched in February (dry) and April (wet)

\begin{tabular}{|c|c|c|c|c|c|c|c|c|c|c|c|c|}
\hline \multirow[t]{2}{*}{ Well sample } & \multicolumn{2}{|c|}{$\begin{array}{l}\text { Ave. tempera- } \\
\text { ture }\left({ }^{\circ} \mathrm{C}\right)\end{array}$} & \multicolumn{2}{|c|}{ Ave. $\mathrm{pH}$} & \multicolumn{2}{|c|}{$\begin{array}{l}\text { Ave. TDS } \\
\text { (mg/L) }\end{array}$} & \multicolumn{2}{|c|}{$\begin{array}{l}\text { Ave. DO } \\
\text { (mg/L) }\end{array}$} & \multicolumn{2}{|c|}{$\begin{array}{l}\text { Ave. EC ( } \mu \mathrm{S} / \\
\mathrm{cm})\end{array}$} & \multicolumn{2}{|c|}{$\begin{array}{l}\text { Ave. salinity } \\
\text { (ppt) }\end{array}$} \\
\hline & Dry & Wet & Dry & Wet & Dry & Wet & Dry & Wet & Dry & Wet & Dry & Wet \\
\hline WA & 29.72 & 29.98 & 6.22 & 6.58 & 1490 & 1310 & 6.45 & 6.25 & 2340 & 2050 & 1.20 & 1.00 \\
\hline WB & 28.53 & 29.08 & 5.80 & 6.41 & 550 & 490 & 5.71 & 4.49 & 860 & 780 & 0.40 & 0.40 \\
\hline$w C$ & 28.65 & 28.41 & 6.77 & 6.95 & 750 & 740 & 4.50 & 4.68 & 1180 & 1160 & 0.60 & 0.60 \\
\hline$w D$ & 29.59 & 29.40 & 5.37 & 5.80 & 460 & 490 & 2.10 & 7.93 & 710 & 770 & 0.30 & 0.40 \\
\hline$w E$ & 29.90 & 29.83 & 6.37 & 6.50 & 850 & 990 & 5.00 & 6.22 & 1330 & 1540 & 0.70 & 0.80 \\
\hline wF & 29.81 & 29.71 & 6.10 & 7.02 & 570 & 580 & 7.52 & 5.67 & 900 & 900 & 0.40 & 0.40 \\
\hline$w G$ & 30.14 & 30.04 & 5.15 & 5.47 & 260 & 260 & 3.97 & 7.06 & 400 & 100 & 0.20 & 0.20 \\
\hline . & 32.43 & 30.36 & 6.33 & 6.72 & 840 & 780 & 5.00 & 7.23 & 1310 & 1180 & 0.60 & 0.60 \\
\hline wl & 28.55 & 29.31 & 6.13 & 6.41 & 240 & 250 & 5.94 & 6.08 & 370 & 390 & 0.20 & 0.20 \\
\hline WJ & 28.37 & 28.37 & 5.76 & 6.17 & 490 & 470 & 5.65 & 6.09 & 760 & 740 & 0.40 & 0.40 \\
\hline
\end{tabular}

Ave. average value 
Table 3 Characterization of the different bacteria species during rainy season in April 2016

\begin{tabular}{|c|c|c|c|c|c|c|c|c|c|}
\hline Well sample & $\begin{array}{l}\text { Triple } \\
\text { sugar } \\
\text { iron }\end{array}$ & $\begin{array}{l}\text { Citrate } \\
\text { utilization } \\
\text { test }\end{array}$ & Indole test & Urease test & $\begin{array}{l}\text { Lactose } \\
\text { fermenta- } \\
\text { tion }\end{array}$ & Catalase test & $\begin{array}{l}\text { Haemolysis } \\
\text { type on blood } \\
\text { agar }\end{array}$ & $\begin{array}{l}\text { Gram } \\
\text { stain- } \\
\text { ing }\end{array}$ & $\begin{array}{l}\text { Suspected/pos- } \\
\text { sible pathogen }\end{array}$ \\
\hline \multirow[t]{3}{*}{$w_{3}$} & - & - & + & - & - & $\mathrm{N} / \mathrm{A}$ & $\mathrm{N} / \mathrm{A}$ & - & E. coli \\
\hline & - & + & - & + & N/A & - & $\mathrm{N} / \mathrm{A}$ & - & Klebsiella spp. \\
\hline & N/A & $\mathrm{N} / \mathrm{A}$ & $\mathrm{N} / \mathrm{A}$ & $\mathrm{N} / \mathrm{A}$ & $\mathrm{N} / \mathrm{A}$ & - & $\beta$ Haemolysis & + & Streptococcus spp. \\
\hline$w B_{3}$ & - & + & - & + & $\mathrm{N} / \mathrm{A}$ & - & N/A & - & Klebsiella spp. \\
\hline \multirow[t]{2}{*}{$\mathrm{wC}_{3}$} & - & + & - & + & N/A & - & $\mathrm{N} / \mathrm{A}$ & - & Klebsiella spp. \\
\hline & - & - & + & - & - & $\mathrm{N} / \mathrm{A}$ & $\mathrm{N} / \mathrm{A}$ & - & E. coli \\
\hline $\mathrm{wD}_{3}$ & - & + & - & + & N/A & - & $\mathrm{N} / \mathrm{A}$ & - & Klebsiella spp. \\
\hline \multirow[t]{2}{*}{$w E_{3}$} & - & + & - & + & N/A & - & N/A & - & Klebsiella spp. \\
\hline & - & - & + & - & - & $\mathrm{N} / \mathrm{A}$ & N/A & - & E. coli \\
\hline \multirow[t]{3}{*}{$\mathrm{wF}_{3}$} & - & + & - & + & $\mathrm{N} / \mathrm{A}$ & - & $\mathrm{N} / \mathrm{A}$ & - & Klebsiella spp. \\
\hline & - & - & + & - & - & $\mathrm{N} / \mathrm{A}$ & $\mathrm{N} / \mathrm{A}$ & - & E. coli \\
\hline & $\mathrm{N} / \mathrm{A}$ & $\mathrm{N} / \mathrm{A}$ & $\mathrm{N} / \mathrm{A}$ & $\mathrm{N} / \mathrm{A}$ & N/A & + & $\mathrm{N} / \mathrm{A}$ & + & Bacillus spp. \\
\hline \multirow[t]{2}{*}{$w G_{3}$} & - & + & - & + & N/A & - & N/A & - & Klebsiella spp. \\
\hline & $\mathrm{N} / \mathrm{A}$ & $\mathrm{N} / \mathrm{A}$ & $\mathrm{N} / \mathrm{A}$ & N/A & $\mathrm{N} / \mathrm{A}$ & + & $\mathrm{N} / \mathrm{A}$ & + & Bacillus spp. \\
\hline \multirow[t]{3}{*}{$\mathrm{wH}_{3}$} & - & + & - & + & N/A & - & $\mathrm{N} / \mathrm{A}$ & - & Klebsiella spp. \\
\hline & $\mathrm{N} / \mathrm{A}$ & $\mathrm{N} / \mathrm{A}$ & $\mathrm{N} / \mathrm{A}$ & $\mathrm{N} / \mathrm{A}$ & $\mathrm{N} / \mathrm{A}$ & + & $\mathrm{N} / \mathrm{A}$ & + & Bacillus spp. \\
\hline & - & - & + & - & - & N/A & $\mathrm{N} / \mathrm{A}$ & - & E. coli \\
\hline \multirow[t]{3}{*}{$\mathrm{wl}_{3}$} & - & + & - & + & $\mathrm{N} / \mathrm{A}$ & - & N/A & - & Klebsiella spp. \\
\hline & - & - & + & - & - & $\mathrm{N} / \mathrm{A}$ & $\mathrm{N} / \mathrm{A}$ & - & E. coli \\
\hline & $\mathrm{N} / \mathrm{A}$ & $\mathrm{N} / \mathrm{A}$ & $\mathrm{N} / \mathrm{A}$ & N/A & N/A & + & $\mathrm{N} / \mathrm{A}$ & + & Bacillus spp. \\
\hline \multirow[t]{3}{*}{$\mathrm{wJ}_{3}$} & - & + & - & + & $\mathrm{N} / \mathrm{A}$ & - & $\mathrm{N} / \mathrm{A}$ & - & Klebsiella spp. \\
\hline & - & - & + & - & - & N/A & $\mathrm{N} / \mathrm{A}$ & - & E. coli \\
\hline & $\mathrm{N} / \mathrm{A}$ & $\mathrm{N} / \mathrm{A}$ & $\mathrm{N} / \mathrm{A}$ & $\mathrm{N} / \mathrm{A}$ & $\mathrm{N} / \mathrm{A}$ & + & $\mathrm{N} / \mathrm{A}$ & + & Bacillus spp. \\
\hline
\end{tabular}

N/A not applicable, ' + '- positive results (present), ${ }^{\prime}-$ '-negative results (absent)

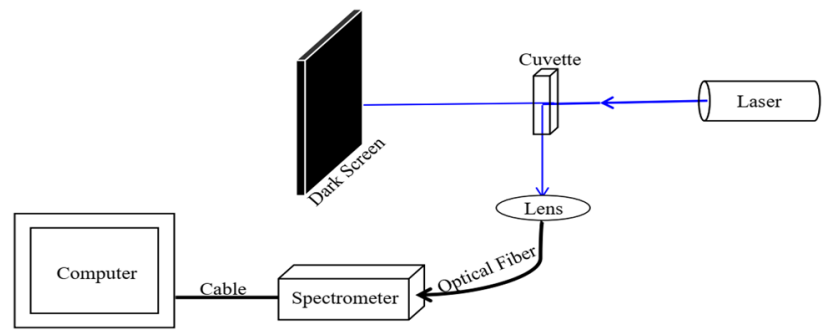

Fig. 3 Schematic diagram of the LIF system for water DOM studies

interfaced to a computer [29]. Data acquisition parameters were set as follows: LIF spectra integration time was typically preset to $300 \mathrm{~ms}$ for longer exposure time of water samples; the LIF spectra acquisition time was preset to $180 \mathrm{~s}$; and smoothening boxcar was preset to 10-30. The system was calibrated using single-distilled water sample. The spectra position of the water Raman peak $\left(\lambda_{\mathrm{m}}\right)$ depends on the excitation wavelength $\left(\lambda_{\mathrm{ex}}\right)$, and it can be estimated using Eq. (1).
Water Raman peak position $\left[\lambda_{\mathrm{m}}(\mathrm{nm})\right]=\left(\frac{1 \times 10^{7}}{\lambda_{\mathrm{ex}}}-3400\right)^{-1}$

where $\lambda_{\mathrm{ex}}=445 \mathrm{~nm}, \lambda_{\mathrm{m}}=524.3 \mathrm{~nm}$.

In this study, this is close to the experimental water Raman peak of $527 \mathrm{~nm}$ for the distilled water, thereby showing the sensitivity of our LIF system. Nevertheless, it is important to note that the size and shape of the Raman scatter peak are dependent on the instrument optics, setup (e.g. bandwidths, PMT voltage) and lamp age [16].

\section{Data analysis}

Data analysis for the LIF was carried out using MATLAB version 7.11, and graphs were generated in Microsoft Excel version 2013. The inelastic scattering of laser emission on water molecules is the Raman scattering signal, the Raman line which is usually used as a means of standardization for fluorescence signal [16]. In this study, fluorescence intensity data were corrected for inner filter effect (IFE) by 
normalizing to the water Raman peak of the distilled water at $527 \mathrm{~nm}$ [30]. This approach is applicable, since currently there is no standardized approach to correct DOM samples for IFE, and its applicability to low concentration of DOM in hand-dug well water samples is accepted [20]. No further corrections were made to the experimental spectra, e.g. blank subtraction to compensate for instrument biases or fluctuation of instrumental factors. Blank subtraction was omitted from the study procedure since its application for low concentration of DOM samples (or dilute samples) is questionable [65]. This could have been the case in analysis of a three-dimensional excitation-emission matrix (EEM). For this study to be valid, the authors used a fixed excitation wavelength of $445 \mathrm{~nm}$ as already mentioned, and collected only one set of emission wavelengths ranging from 450 to $750 \mathrm{~nm}$, ensuring that no changes in the lamp intensity during the measurement period occurred. For this reason, at least on a qualitative basis water quality based on DOM should be allowed $[49,60]$. However, the quantitative analysis of the DOM in each well water system has been considered in arbitrary units (a.u.) from the instrument used rather than well-defined quantities as a water quality indicator; yet in this study, DOM fluorescence intensity (a.u.) is an indicator of water quality changes in well water systems (Fig. 5). Furthermore, both PCA and CA techniques were used to evaluate the similarity or dissimilarity among the water samples [44]. Additionally, the K-nearest neighbour (K-NN) technique based on the Euclidean distance between each water sample and distilled water has been used to classify the samples into very good, good, fairly good and bad water samples, with the distilled water used as the benchmark for DOM-free water sample. Thus, in this study, the nearness of each well water sample to the distilled water was qualitatively and quantitatively measured. The K-NN algorithm was used as a robust and versatile classifier method, basic and simpler
$[42,44]$; yet, it has many advantages over other classifiers such as support vector machines (SVMs), discriminant analysis, classification trees and probabilistic neural networks $[27,35,54,55]$. As a result, the performance of the K-NN is comparable to that of its competitors such as decision trees and neural networks. Therefore, in this study each set of data (from the ten wells) obtained is the set with maximum fluorescence intensity selected among the multiple spectra of the multiple fetches for each month. Accordingly, the various spectra (Fig. 5) were labelled wA1 through wJ1, wA2 through wJ2 and wA3 through wJ3 for February, March and April, correspondingly, for each year.

\section{Results and discussion}

\subsection{Groundwater quality}

\subsubsection{Identification of DOM using laser-induced fluorescence spectroscopy}

The two broad shoulders at 480-500 $\mathrm{nm}$ and 550-570 nm, engulfing the water Raman peak within $527.0 \pm 2.0 \mathrm{~nm}$ (Fig. 4), are consistent with previous studies by Stedmon et al. [58]. It is important to note that the sharper the water Raman peak, the better the water quality. Fluorescence similar to this was again observed for coloured dissolved organic matter in a wide range of environment and in groundwater well samples [56]. Thus, in this study, fluorescence intensity was influenced by the type of surrounding and activity $[6,23]$ using a fixed excitation and emission wavelengths. Therefore, it is characteristic to note that allochthonous or autochthonous humic-like DOM-type production can
Fig. 4 Sample of a 445-nm LIF measurements: a water Raman peak signal of the distilled water (Blank test) showed negligible DOM signal and b fluorescence spectrum of a polluted well water sample with water Raman peak engulfed by well water DOM fluorescence
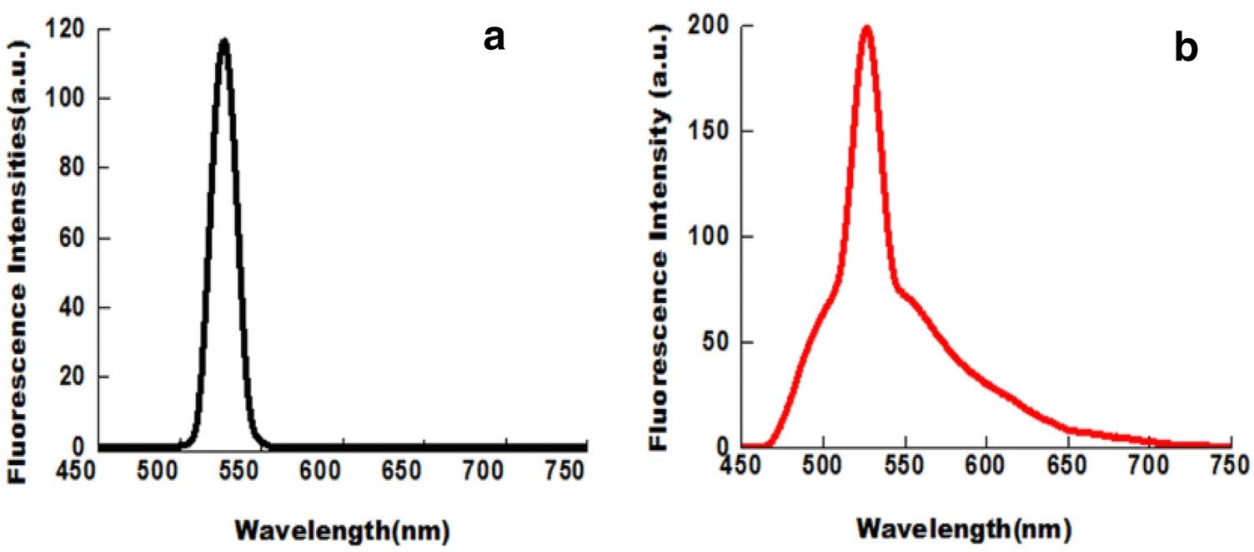

SN Applied Sciences A SPRINGER NATURE journa 

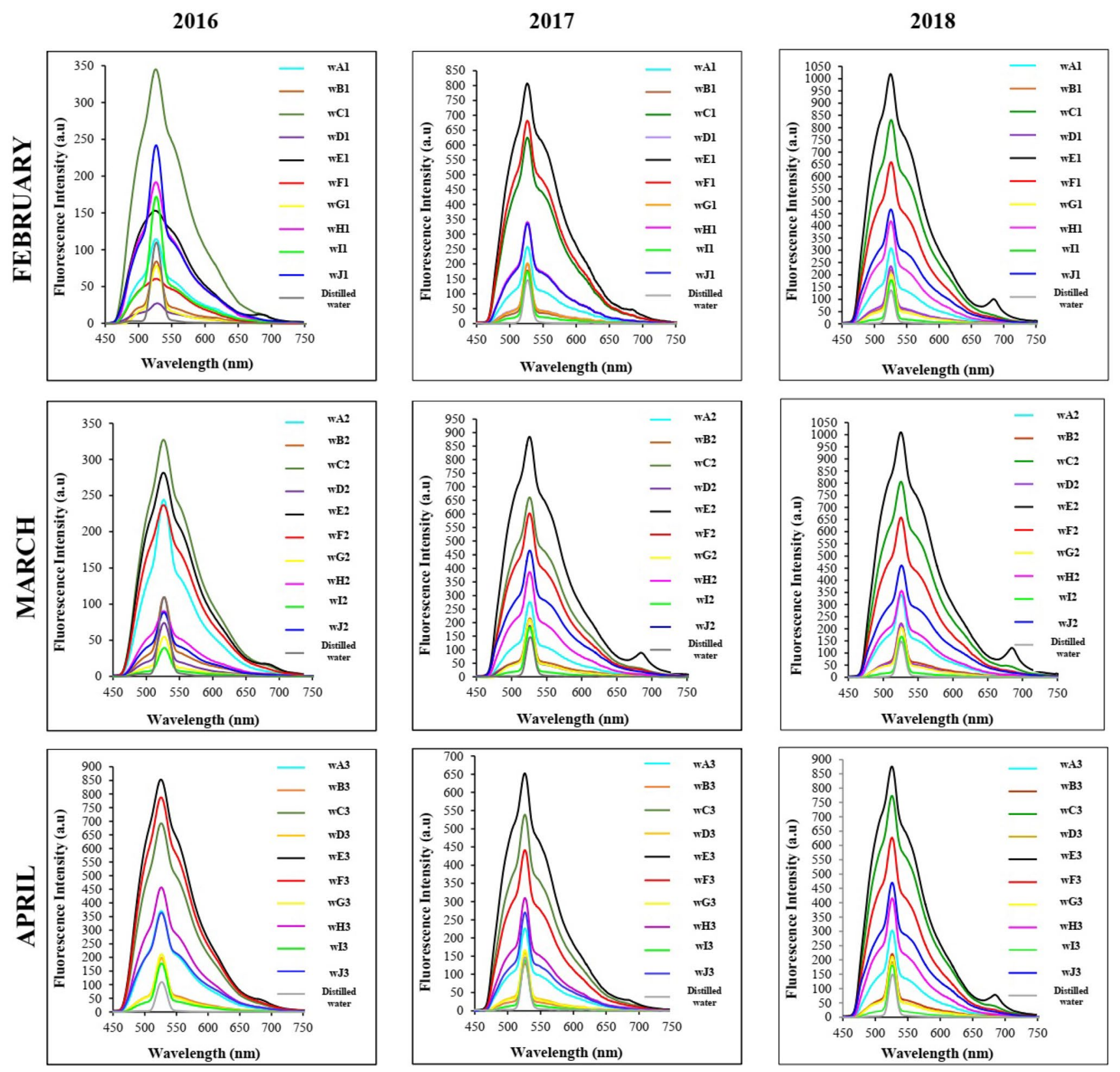

Fig. 5 The LIF spectra of sample fetches for February, March and April of 2016, 2017 and 2018, respectively

be classified as natural or derived from human activity (e.g. human wastes, farm wastes, leachates) through flow path of water, discharge, land-use activities and dry and wet depositions [23]. Thus, the explanations for fluorescence spectra (Fig. 5) observed for 2016, 2017 and 2018 , respectively, have been accounted for. Indeed, the trend observed was the same for the three-year research. However, for the sake of brevity the results of 2016 are hereafter presented.

In February 2016, the DOM fluorescence intensities of the water samples ranged from 15.19 to 250.0 a.u. with the lowest value obtained for sample wD1 and the highest was found for sample wC1. For the same month in 2017, the DOM fluorescence had increased, ranging between 15.57 and 638.97 a.u. with the lowest obtained for sample wl1, and the highest for sample wE1. Interestingly, the 2017 pattern was seen in 2018 with the highest being 803.73 a.u. for sample wE1 and 19.37 a.u. for sample wl1.

In March 2016 (at the onset of the rainy season), the lowest DOM fluorescence intensity was observed for sample wI2, which is located in an arid land, not close to a septic tank or public toilet. The highest humic-like DOM fluorescence intensity was found in sample wC2, and this could be due to the fact that well wC is located in a 
wetland environment and close to a septic tank (Table 1). The age and the nature of the walls of well wC might have contributed to the observed fluorescence intensities (a.u.). Similar explanation can be given for the DOM fluorescence intensities observed in 2017 and 2018 during the same month. However, for 2017, the fluorescence intensities increased ranging from 19.75 to 689.36 a.u., with sample wl2 having the lowest fluorescence intensity value, and sample wE2, the highest. The 2018, DOM fluorescence intensity values ranged from 14.70 a.u. for 12 to 805.95 a.u. for $w E 2$. The high values of the DOM fluorescence intensities obtained in 2017 and 2018 could be attributed to the fact that well $W E$ is located in a wetland environment and close to a septic tank (Table 1), and there was an increase in rainfall within the period.

In April 2016, during the rainy season, the DOM fluorescence intensities ranged from 41.84 to 743.26 a.u., with sample wl3 having the lowest fluorescence intensity, and sample wE3, the highest. The DOM fluorescence intensity for April 2017 ranged from 14.02 to 581.08 a.u. with wl3 as the sample with the lowest intensity, and WE3 having the highest. The reason, as previously given, may validate the differences. However, the decrease in intensity may be due to lack of intense rainfall during the same month in 2017, due to climate change. On the other hand, in 2018 the fluorescence intensities (a.u.) observed ranged from 20.53 a.u. for sample wl3 to 688.61 a.u. for sample wE3. Thus, rainfall levels do affect DOM fluorescence intensity in addition to the deterioration of the walls of the wells and their locations.

Actually, the emission spectra obtained in this study are characterized by broad bands of relatively low fluorescence intensities (a.u) and maximum emission wavelengths which vary in a limited range showing that the samples are of similar origin and nature [36]. The relative low fluorescence intensities indicate dilute samples. In this study, the authors' assessment of the levels of DOM on seasonal and both spatial and temporal scales, has been mainly qualitative. The fluorophore intensity (a.u.) of the LIF spectra shoulders have been used as a qualitative measure of the DOM concentration levels of the fluorophore in fluorescent intensity of arbitrary unit (a.u.) equivalent to $\mathrm{ppm}$ or ppb concentration levels $[24,38]$ in the water samples. To this end, to discriminate between the levels of contamination, it is possible to quantify the degree of water contamination by checking the ratio between different fluorescence peaks [16] or parts, without subtracting the area under the standardized peak (Fig. 4a) from the spectra area of each contaminated sample [16], although some studies have used various fluorescence indices to show the extent of discrimination among contaminated drinking water samples.
In general, the authors acknowledge that wells which were not covered also showed increased DOM fluorescence during the rainy season. This is so because rainwater brings considerable amounts of dissolved organic matter (DOM) in fractions of low aromaticity and humification degree from the atmosphere to freshwater and marine environments, but little is known about the chemical composition and bioavailability of rainwater DOM [64]. With regard to seasonality, higher concentrations of humic-like DOM were observed during the wet season as a result of leachates from toilets and wetlands, old refuse damps, septic tanks and marshy areas. In contrast, the dry season resulted in much lower concentrations of humiclike DOM. Thus, different hydrological processes seem to be the dominant drivers of seasonality for the well sites studied [14]. Therefore, in this study, the increased humiclike DOM fluorescence intensity trend observed over the three-year period could be due to certain hydrological processes like dominant drivers of seasonality for the sites [14] which needs to be studied further. The deterioration of the walls of the wells might have allowed leachates into the water bodies. Throughout the study period, DOM fluorescence intensity increased in the rainy season; the dry season intensities were mostly low. Thus, the rise in fluorescence intensity of humic DOM substances in the well waters may be a consequence of the input of newly formed humic substances. For example, water samples obtained from wells located in wetlands exhibited higher DOM fluorescence intensities than those obtained from wells in arid lands. However, it is well known that the labile constituents of DOM in aquatic environments provide metabolism substrates for microbial growth and would be decomposed to $\mathrm{CO} 2$ [7]. Previous studies on aquatic DOM have indicated that the humic fraction of DOM is mainly responsible for the absorbance of UV light and for the photoproduction of labile substrates that can be subsequently utilized by bacteria. Accordingly, [63] found that aromatic substances including protein- and humic-like matter are easily absorbed by minerals in aquifer, and compared to protein-like substances, humic-like substances are more easily absorbed by minerals, and the humic-like matter concentration exhibited no significant change even though groundwater contamination occurred [19].

\subsubsection{Classification using multivariate statistical evaluation}

Principal component analysis (PCA) based on the treated raw data of the LIF results was performed on all the water samples for 2016, 2017 and 2018 to help discriminate DOM from different sources and/or subject to different transformations in aquatic environments/seasons. Generally, PCA is an effective statistical tool, and it was used to quantify and categorize 

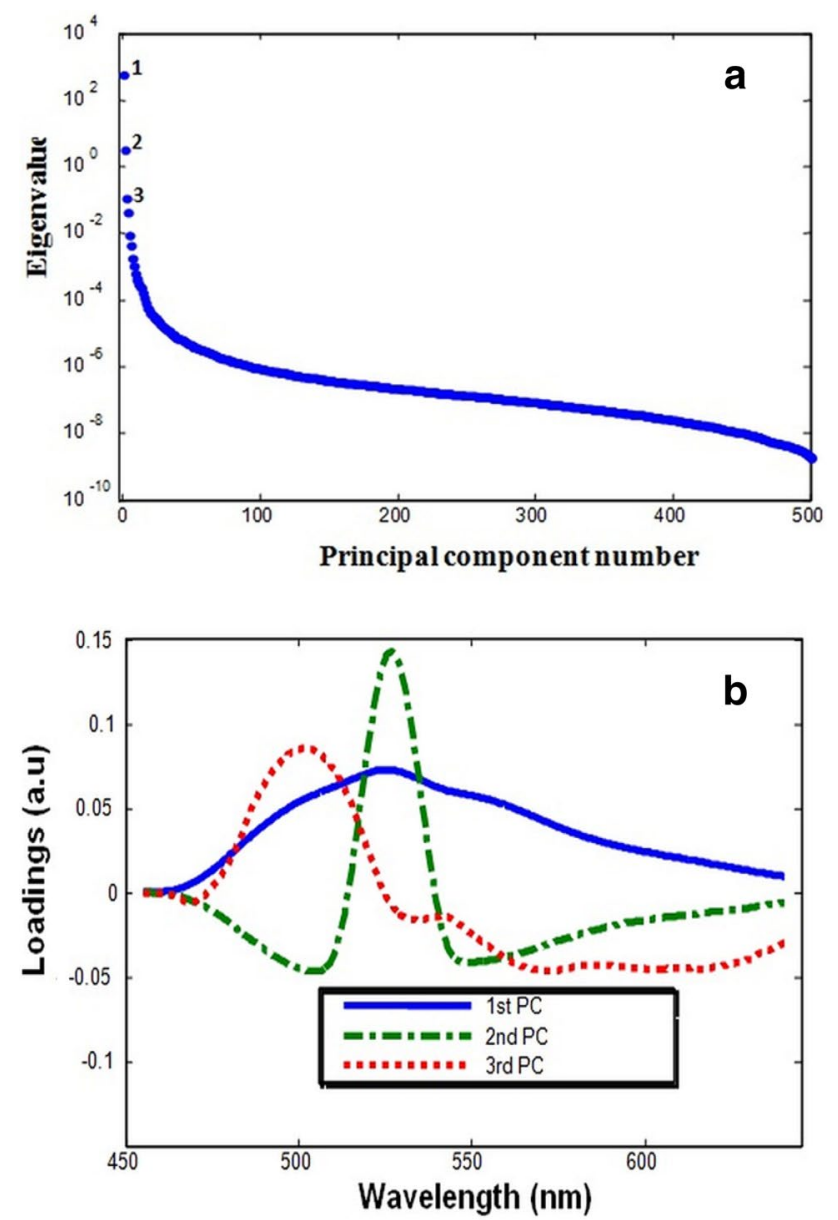

Fig. 6 a Scree plot of the eigenvalues of the principal component numbers; the first three eigenvalues have the most of the information regarding the samples, $\mathbf{b}$ loadings versus wavelength of the first three principal components

the similarity among the water samples. From the fluorescence intensity-emission graphs (Fig. 5) of 2016, in order to obtain conclusive results, the spectra within the region 460-640 $\mathrm{nm}$ were used, which amounts to 162 spectra intensities per sample. Statistically, this is more preferable. Figure 6 elucidates the scree plot of the eigenvalues of the principal component numbers and the loadings versus wavelength of the first three principal components. The first three eigenvalues have most of the information regarding the samples. According to the principle of elbow test [26], the truncation (tr) value was determined to be 3 . The loadings of $P C 1$ and $P C 2$ were considered since eigenvalues below $10^{\circ}(=1)$ were deemed insignificant. This means that $P C 1$ and $P C 2$ were of high significance for the classification of the quality of the well water samples. In other words, the variance for PC1 shows that more than $99 \%$ contributed most significantly to the DOM contamination in the water samples.

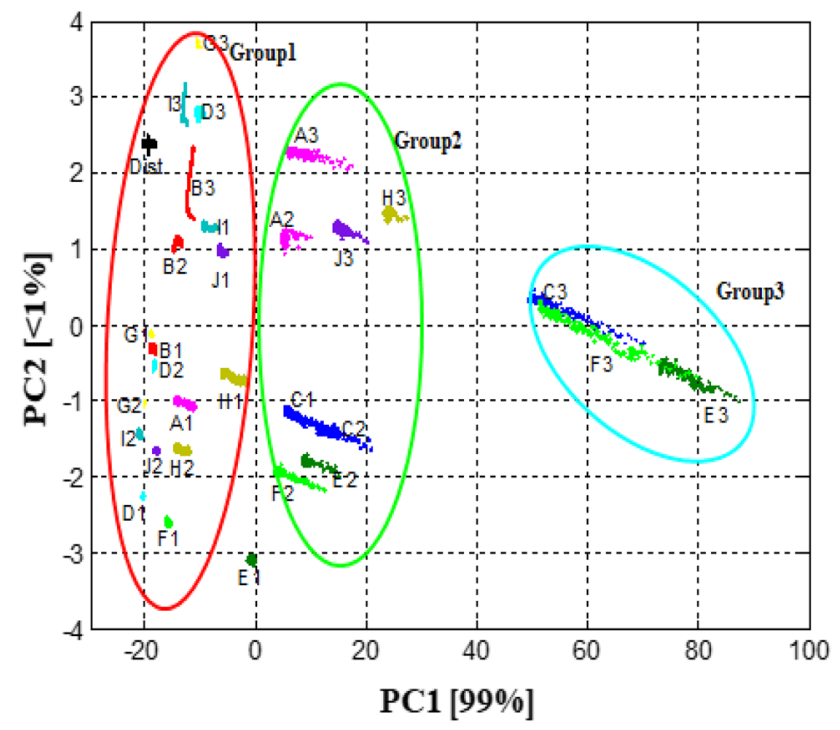

Fig. 7 Scatter plot of the first two principal components discriminating the water samples

PC2 contributed less than $1 \%$ variance which might be due to the $\mathrm{O}-\mathrm{H}$ bond of the water component in the samples. Characteristically, the loadings depicted that PC3 does not contribute significantly to the classification of the water samples. For detailed description of the principal component analysis, the reader is encouraged to refer to the work of $[8,62]$.

A scatter plot (Fig. 7) of PC1 and PC2 for distilled water and the well water samples shows three distinct groups of water samples labelled Groups 1, 2 and 3, respectively. Group 1 consists of 20 water samples including 19 well water samples and the distilled water. The well water samples in Group 1 are characterized by low fluorescence backgrounds (intensities) and sharp water Raman peaks. To this end, Group 1 is likely to consist of water samples with low concentrations of DOM. Group 2 is a cluster of samples A2, A3, H3, J3, C1, C2, E2 and F2. The fluorescence spectra of these samples are characterized by moderately high fluorescence intensities (DOM concentrations) and broad water Raman peaks. Samples C3, E3 and F3, which are located on the far right of the PCA score plot, are the constituents of Group 3. In this group, the DOM fluorescence peak intensities are the highest and broadest, with broader water Raman peaks as compared to those in Group 2.

Although Group 3 samples have the highest water Raman peaks, they are classified as the most contaminated water samples due to their relatively high DOM concentrations (Fig. 5). Principal component analysis (PCA) based on DOM indices revealed two principal factors, which were related to the concentration and humic-type DOM, respectively [31]. Most significantly, the clustering in the PCA 
Fig. 8 Cluster analysis among water samples (Ward method of normalized data) for ten sampling sites

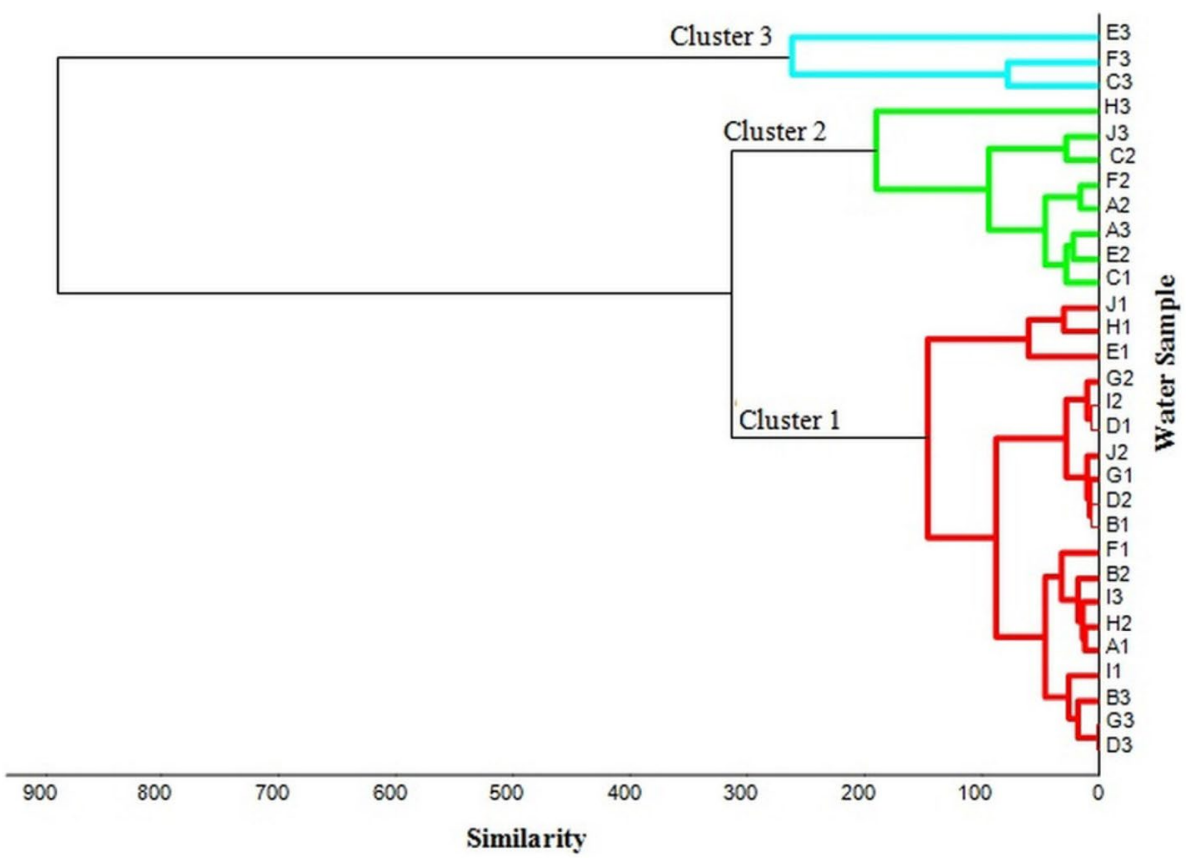

score plots (Fig. 7) is consistent with the clusters in Fig. 8, the tree of cluster. Evidently, it shows its ability for the classification of the water samples. In the cluster analysis (CA), the fetches are grouped based on the similarities within a cluster and dissimilarities among the different clusters [39].

In this regard, the Euclidean distance measure examines the similarity and/or dissimilarity (Fig. 8). Group 1 (Fig. 7) relates to Cluster 1 (Fig. 8) with their membership. Similarly, Group 2 relates to Cluster 2, and Group 3 to Cluster 3 in that manner. Based on the dendrogram, the similarities and the dissimilarities in the water samples are again evident. Clusters 1 and 2 are very similar to each other with little marked difference, yet they are unlike those in Cluster 3. With regard to members of Cluster 3 , samples $\mathrm{C} 3$ and $\mathrm{F} 3$ are similar and yet dissimilar to sample E3.

\subsubsection{Classification based on K-nearest neighbour (K-NN)}

The quality of the water samples studied in 2016 (with regard to DOM contamination levels) was classified using K-nearest neighbour (K-NN) algorithm based on Euclidean distance. This method is strictly based on simple Euclidean distances between one data point (e.g. the singly distilled water) and the well water samples; the shortest distance describes the best water quality. A bar chart (Fig. 9) of Euclidean distances of the well water samples based on similarity measurement shows that B1 corresponds to the shortest Euclidean distance and E3 the longest. Using this range, we classified the samples as being very good, good, fairly good and bad. For example, B1, D2, G1, G2 and 12 are considered as very good water samples; A1, B3, D1, D3, E1,

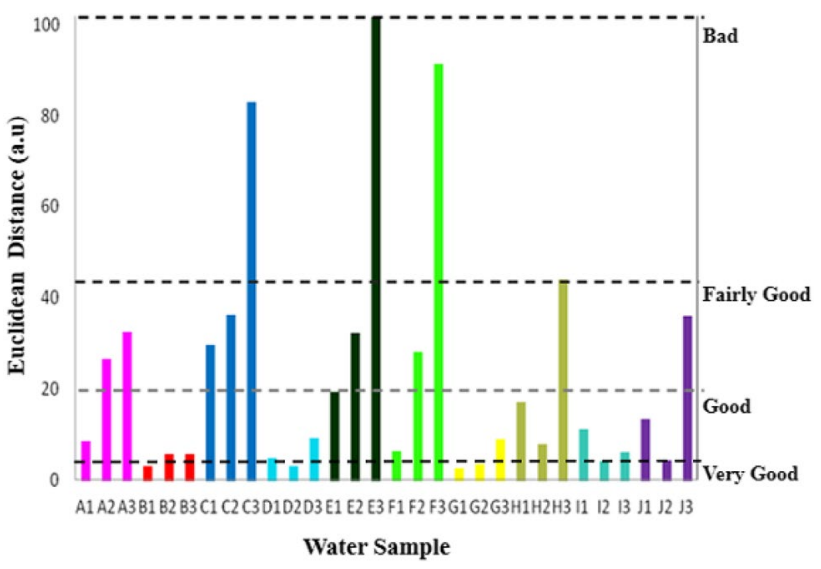

Fig. 9 Euclidean distances from one data point (singly distilled water) to all other well water samples in two dimensions for K-nearest neighbour test for water purity classification

$\mathrm{F} 1, \mathrm{G} 3, \mathrm{H} 1$ and $\mathrm{H} 2$ are deemed good; $\mathrm{A} 2, \mathrm{~A} 3, \mathrm{C1}, \mathrm{C2}, \mathrm{E} 2, \mathrm{~F} 2$, $\mathrm{H} 3$ and $\mathrm{J} 3$ as fairly good; and $\mathrm{C} 3, \mathrm{E} 3$ and $\mathrm{F} 3$ as bad water samples. The same classification can be obtained from the physical parameters such as colour, odour and the taste of the water samples. In this case, K-NN based on Euclidean distance can be used as a tool for effective water quality classification in addition to other statistical tools such as used in this study. Following on this, a $3 \times 4$ sample matrix chart (Fig. 10) extracted from Fig. 9 shows the fluorescence fingerprints of three each of the above classifications, vis-à-vis: very good (first row from top), good (second row from top), fairly good (third row from top) and bad (fourth row, bottom) water samples are depicted. 

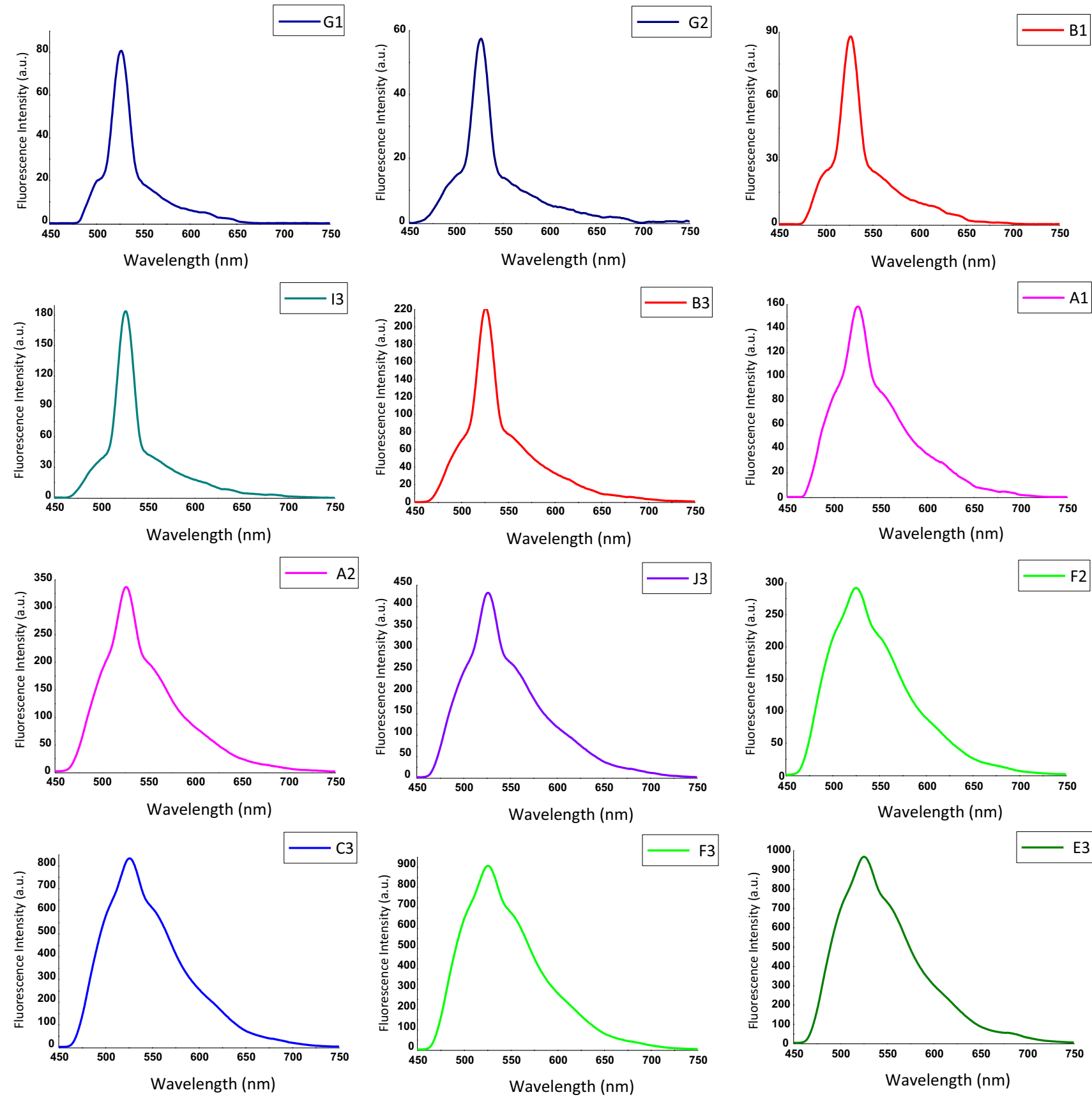

Fig. 10 A $3 \times 4$ sample matrix presentation of LIF spectra of the water samples as discriminated by K-NN test: very good (first row from top), good (second row from top), fairly good (third row from top) and bad (fourth row from bottom)

\section{Conclusions}

In this study, for the first time, groundwater quality assessment has been tied together with DOM fluorescence, K-NN and other statistical analyses, in evidence as a potential diagnostic tool for both laboratory and in situ effective investigation and classification of DOM contamination levels in well water for drinking and other household chores. Also, the research effort presented several opportunities for future research with potential application in drinking water resources and treatment monitoring at places where access to potable drinking water still remains a challenge. The common trend observed with the LIF spectra showed that the levels of DOM contamination depended on the locations of the wells and the seasons of fetch. In other words, the study indicated that DOM fluorescence is an indicator of water quality changes in well water systems. The levels of contamination increased from 2016 to 2018 
during the rainy seasons and for the wells in close proximity to septic tanks, refuse dumps, public toilets, and in wetlands. The age of the wells also contributed significantly to the levels of DOM contaminations observed. In general, the sources of DOM contaminants in the wells are both autochthonous and allochthonous, although the fluorescence intensity peaks (a.u) indicated low levels in the wells, yet despite the low DOM content, its disinfection may result in formation of toxic organic substances. It is important to note that hand-dug wells should not be sited in areas prone to higher levels of DOM contaminants. Nevertheless, water fetched from contaminated wells, especially during the rainy seasons, must be well treated before use. Additionally, owners of age-old hand-dug wells with cracked walls need to dewater such wells and reconstruct the walls to prevent leaching of DOM contaminants into the water system.

Acknowledgements The authors of this paper will like to acknowledge Mr. Daniel Ackom for his support during field sampling. We also appreciate the contribution of Mr. Richard Adade of the Geography and Regional Planning, UCC, for acquiring the map of the study area.

Funding This work was supported by a grant from the Directorate of Research, Innovation, and Consultancy (DRIC) of the University of Cape Coast (UCC), Ghana, a financial support from the Office of External Activities (OEA) of ICTP, Trieste and equipment support from the International Program for Physical Sciences (IPPS) of International Science Program (ISP), Uppsala to the Laser and Fibre-Optic Centre (LAFOC) of the Department of Physics of UCC.

\section{Compliance with ethical standards}

Conflict of interest On behalf of all authors, the corresponding author states that there is no conflict of interest.

\section{References}

1. Abanyie SK, Boateng A, Ampofo S (2016) Investigating the potability of water from dug wells: a case study of the Bolgatanga Township. Ghana 10(October):307-315. https://doi.org/10.5897/ AJEST2016.2127

2. Adeboye MO (2014) Disinfection of Escherichia coli in water using ultraviolet-LEDs. Theses and dissertations

3. Allouche $J$ (2011) The sustainability and resilience of global water and food systems: political analysis of the interplay between security, resource scarcity, political systems and global trade. Food Policy 36(SUPPL. 1):S3. https://doi.org/10.1016/j. foodpol.2010.11.013

4. Armah FrederickA, Obiri $\mathrm{S}$, Yawson DO, Onumah EE, Yengoh GT, Afrifa EKA, Odoi JO (2010) Anthropogenic sources and environmentally relevant concentrations of heavy metals in surface water of a mining district in Ghana: a multivariate statistical approach. J Environ Sci Health A Toxic Hazard Subst Environ Eng 45(13):1804-1813. https://doi.org/10.1080/10934 529.2010 .513296

5. Armah FrederickAto (2014) Relationship between coliform bacteria and water chemistry in groundwater within gold mining environments in Ghana. Water Qual Expo Health 5(4):183-195. https://doi.org/10.1007/s12403-014-0110-1

6. Baker A, Spencer RGM (2004) Characterization of dissolved organic matter from source to sea using fluorescence and absorbance spectroscopy. Sci Total Environ 333(1-3):217-232. https://doi.org/10.1016/j.scitotenv.2004.04.013

7. Bodmer P, Heinz M, Pusch M, Singer G, Premke K (2016) Carbon dynamics and their link to dissolved organic matter quality across contrasting stream ecosystems. Sci Total Environ 553:574-586. https://doi.org/10.1016/j.scitotenv.2016.02.095

8. Brems M (2017) A one-stop shop for principal component analysis. Retrieved from data science website: https://towar dsdatascience.com/a-one-stop-shop-for-principal-compo nent-analysis-5582fb7e0a9c. Accessed 13 Mar 2020

9. Bridgeman J, Baker A, Carliell-Marquet C, Carstea E (2013) Determination of changes in wastewater quality through a treatment works using fluorescence spectroscopy. Environ Technol 34(21-24):3069-3077

10. Brydegaard M, Merdasa A, Gebru A, Jayaweera H, Svanberg S (2016) Realistic instrumentation platform for active and passive optical remote sensing. Appl Spectrosc 70(2):372-385. https://doi.org/10.1177/0003702815620564

11. Burns IS, Kaminski CF (2011) Diode laser induced fluorescence for gas-phase diagnostics. Zeitschrift Fur Physikalische Chemie 225(11-12):1343-1366. https://doi.org/10.1524/ zpch.2011.0182

12. Carstea EM, Popa CL, Baker A (2019) In situ fluorescence measurements of dissolved organic matter: a review. Sci Total Environ. https://doi.org/10.1016/j.scitotenv.2019.134361

13. Carstea EM, Baker A, Bieroza M, Reynolds DM, Bridgeman J (2014) Characterisation of dissolved organic matter fluorescence properties by PARAFAC analysis and thermal quenching. Water Res 61:152-161. https://doi.org/10.1016/j.watres.2014.05.013

14. Chen M, Maie N, Parish K, Jaffé R (2013) Spatial and temporal variability of dissolved organic matter quantity and composition in an oligotrophic subtropical coastal wetland. Biogeochemistry 115(1-3):167-183. https://doi.org/10.1007/s10533-013-9826-4

15. Copa WM, Gitchel WB (1981) U.S. Patent No. 4265747. U.S. Patent and Trademark Office, Washington, DC

16. Ghervase L, Carstea EM, Pavelescu G, Savastru D (2010) Laser induced fluorescence efficiency in water quality assessment. Roman Rep Phys 62(3):652-659

17. Gondal MA, Dastageer MA, Khalil A (2009) Synthesis of nanoWO3 and its catalytic activity for enhanced antimicrobial process for water purification using laser induced photo-catalysis. Catal Commun 11(3):214-219

18. Hanson JEK (2010) Geochemistry of pegmatites associated with the Cape Coast granite complex of southern Ghana (University of Ghana; vol 42). Retrieved from https://inis.iaea.org/search/ search.aspx?orig_q=RN:42023567. Accessed 13 Mar 2020

19. He XS, Xi BD, Gao RT, Wang L, Ma Y, Cui DY, Tan WB (2015) Using fluorescence spectroscopy coupled with chemometric analysis to investigate the origin, composition, and dynamics of dissolved organic matter in leachate-polluted groundwater. Environ Sci Pollut Res 22(11):8499-8506. https://doi.org/10.1007/ s11356-014-4029-7

20. Henderson RK, Baker A, Murphy KR, Hambly A, Stuetz RM, Khan SJ (2009) Fluorescence as a potential monitoring tool for recycled water systems: a review. Water Res 43:863-881. https://doi. org/10.1016/j.watres.2008.11.027

21. Hirose K (2007) Metal-organic matter interaction: Ecological roles of ligands in oceanic DOM. Appl Geochem 22(8 SPEC. ISS):1636-1645. https://doi.org/10.1016/j.apgeo chem.2007.03.042

22. Hood E, Williams MW, Mcknight DM (2005) Sources of dissolved organic matter (DOM) in a Rocky Mountain stream using 
chemical fractionation and stable isotopes. Biogeochemistry 74(2):231-255. https://doi.org/10.1007/s10533-004-4322-5

23. Hudson N, Baker A, Reynolds D (2007) Fluorescence analysis of dissolved organic matter in natural, waste and polluted waters-a review. River Res Appl 23(6):631-649. https://doi. org/10.1002/rra.1005

24. Hudson N, Baker A, Ward D, Reynolds DM, Brunsdon C, CarliellMarquet C, Browning S (2008) Can fluorescence spectrometry be used as a surrogate for the biochemical oxygen demand (BOD) test in water quality assessment? An example from South West England. Sci Total Environ 391(1):149-158. https://doi. org/10.1016/j.scitotenv.2007.10.054

25. Huguet A, Vacher L, Relexans S, Saubusse S, Froidefond JM, Parlanti E (2009) Properties of fluorescent dissolved organic matter in the Gironde Estuary. Org Geochem 40(6):706-719. https://doi. org/10.1016/j.orggeochem.2009.03.002

26. Jolliffe IT (2002) Choosing a subset of principal components or variables. In: Principal component analysis, 2 nd edn, pp 111118. https://doi.org/10.1007/0-387-22440-8_6

27. Khalil A, Almasri MN, McKee M, Kaluarachchi JJ (2005) Applicability of statistical learning algorithms in groundwater quality modeling. Water Resour Res 41(5):1-16. https://doi. org/10.1029/2004WR003608

28. Kusena W, Beckedahl H (2014) An overview of the city of Gweru, Zimbabwe's water supply chain capacity: towards a demand-oriented approach in domestic water service delivery. GeoJournal 81(2):231-242. https://doi.org/10.1007/s10708-014-9615-1

29. Lakowicz JR (2014) Principles of fluorescence spectroscopy, 3rd ed. https://doi.org/10.1007/978-0-387-46312-4

30. Larsson T, Wedborg M, Turner D (2007) Correction of inner-filter effect in fluorescence excitation-emission matrix spectrometry using Raman scatter. Anal Chim Acta 583:357-363. https://doi. org/10.1016/j.aca.2006.09.067

31. Liyang $Y$, Wei C, Wan-E Z, Qiong C, Wenxin L, Hui W, Weidong G, Chen-Tung AC, Minghua $L$ (2019) Characterization and bioavailability of rainwater dissolved organic matter at the southeast coast of China using absorption spectroscopy and fluorescence EEM-PARAFAC Estuarine. Coast Shelf Sci 217:45-55

32. Ludwig R, Roson R, Zografos C, Kallis G (2011) Towards an interdisciplinary research agenda on climate change, water and security in Southern Europe and neighboring countries. Environ Sci Policy 14(7):794-803. https://doi.org/10.1016/j.envsc i. 2011.04 .003

33. Lutterodt G, Van De Vossenberg J, Y. Hoiting, Kamara AK, Odurokwarteng S, Foppen JWA (2018) Microbial groundwater quality status of hand-dug wells and boreholes in the Dodowa Area of Ghana. Int J Environ Res Public Health 15(730):1-12. https://doi. org/10.3390/ijerph15040730

34. Matilainen A, Gjessing ET, Lahtinen T, Hed L, Bhatnagar A, Sillanpää M (2011) An overview of the methods used in the characterisation of natural organic matter (NOM) in relation to drinking water treatment. Chemosphere 83(11):1431-1442. https://doi. org/10.1016/j.chemosphere.2011.01.018

35. Modaresi F, Araghinejad S (2014) A comparative assessment of support vector machines, probabilistic neural networks, and K-nearest neighbor algorithms for water quality classification. Water Resour Manag 28(12):4095-4111. https://doi. org/10.1007/s11269-014-0730-z

36. Nicola S, Miano TM, Provenzano MR, Brunetti G (1991) Second Logo J Logo. Clin J Pain 4(4):217-222

37. Nyarko ES, Aseidu DK, Osea S, Dampare S, Zakaria N, Hanson J et al (2012) Geochemical characteristics of the basin-type granitoids in the Winneba Area of Ghana. Proc Int Acad Ecol Environ Sci 2(3):177-192
38. Okache J, Haggett B, Ajmal T (2015) UV LED fluorescence based method for detecting organic contaminants in water: a review. Trans Mach Des 3(1):1-10

39. Panda UC, Sundaray SK, Rath P, Nayak BB, Bhatta D (2006) Application of factor and cluster analysis for characterization of river and estuarine water systems-a case study: Mahanadi River (India). J Hydrol 331(3-4):434-445. https://doi.org/10.1016/j. jhydrol.2006.05.029

40. Price RM, Swart PK (2006) Geochemical indicators of groundwater recharge in the surficial aquifer system, Everglades National Park, Florida, USA. Spec Pap Geol Soc Am 404(303):251-266. https://doi.org/10.1130/2006.2404(21)

41. Quevauviller P (2011) Adapting to climate change: reducing water-related risks in Europe-EU policy and research considerations. Environ Sci Policy 14(7):722-729. https://doi. org/10.1016/j.envsci.2011.02.008

42. Rokach $L$ (2010) Pattern classification using ensemble methods series in machine perception and artificial intelligence. In: Bunke $H$, Wang PSP (eds). World Scientific, Singapore

43. Sackey SS, Sefa-Ntiri B, Mensah-Amoah P, Ntow J, Vowotor MK, Huzortey A, Akyea A (2017) Microbial purification in well-water using UV-Vis LEDs and monitoring using laser-induced fluorescence. Appl Phys Res 9(6):36. https://doi.org/10.5539/apr.v9n6p 36

44. Sakizadeh M, Mirzaei R (2016) A comparative study of performance of K-nearest neighbors and support vector machines for classification of groundwater. J Min Environ 7(2):149-164. https ://doi.org/10.22044/jme.2016.480

45. Saraceno JF, Pellerin BA, Downing BD, Boss E, Bachand PAM, Bergamaschi BA (2009) High-frequency in situ optical measurements during a storm event: assessing relationships between dissolved organic matter, sediment concentrations, and hydrologic processes. J Geophys Res Biogeosci 114(4):1-11. https:// doi.org/10.1029/2009JG000989

46. Schwalm M, Zeitz J (2015) Concentrations of dissolved organic carbon in peat soils as influenced by land use and site characteristics-a lysimeter study. Catena 127:72-79

47. Scozzari A, Dotsika $E$ (2016) Threats to the quality of groundwater resources, vol 40. https://doi.org/10.1007/978-3-662-48596 $-5$

48. Semiconductor (2017) What are the advantages and disadvantages of Laser diode? Retrieved from semiconductorForu.com

49. Senesi N, Miano TM, Provenzano MR, Bunnetti G (1991) Characterization, differentiation, and classification of Humic substances by fluorescence spectroscopy. Soil Sci 152(4):259-271

50. Sharikova A, Killinger D (2010) UV-laser and LED fluorescence detection of trace organic compounds in drinking water and distilled spirits. Laser Pulse Phenom Appl. https://doi. org/10.5772/13348

51. Sharikova AV (2009) UV laser and LED induced fluorescence spectroscopy for detection of trace amounts of organics in drinking water and water sources. Graduate Theses and Dissertations. https://scholarcommons.usf.edu/etd/15. Accessed 13 March 2020

52. Shen Y, Chapelle FH, Strom EW, Benner R (2015) Origins and bioavailability of dissolved organic matter in groundwater. Biogeochemistry 122(1):61-78. https://doi.org/10.1007/s1053 3-014-0029-4

53. Silfvast WT (2004) Laser fundamentals. In: GIS fundamentals, 2nd ed. https://doi.org/10.1201/b15757

54. Singh KP, Malik A, Singh VK, Mohan D, Sinha S (2005) Chemometric analysis of groundwater quality data of alluvial aquifer of Gangetic plain, North India. Anal Chim Acta 550(1-2):82-91. https://doi.org/10.1016/j.aca.2005.06.056 
55. Spruill TB, Showers WJ, Howe SS (2002) Application of classification-tree methods to identify nitrate sources in ground water. USGS Staff-Published Research, 20, 1-13

56. Stedmon CA, Markager S (2005) Resolving the variability in dissolved organic matter fluorescence in a temperate estuary and its catchment using PARAFAC analysis. Limnol Oceanogr 50(2):686-697. https://doi.org/10.4319/lo.2005.50.2.0686

57. Stedmon CA, Markager S, Bro R (2003) Tracing dissolved organic matter in aquatic environments using a new approach to fluorescence spectroscopy. Mar Chem 82(3-4):239-254. https://doi. org/10.1016/S0304-4203(03)00072-0

58. Stedmon CA, Seredyńska-Sobecka B, Boe-Hansen R, Le Tallec $\mathrm{N}$, Waul CK, Arvin E (2011) A potential approach for monitoring drinking water quality from groundwater systems using organic matter fluorescence as an early warning for contamination events. Water Res 45(18):6030-6038. https://doi.org/10.1016/j. watres.2011.08.066

59. Teng-Pao $C$, Wei-Shiang $H$, Ting-Chien C, Yi-Lung $Y$ (2019) Fluorescence characteristics of dissolved organic matter (DOM) in percolation water and lateral seepage affected by soil solution (S-S) in a lysimeter test. Sensors 19(18):4016. https://doi. org/10.3390/s19184016

60. Wedborg M, Persson T, Larsson T (2007) On the distribution of UV-blue fluorescent organic matter in the Southern Ocean. Deep Sea Res I 54:1957-1971

61. WHO (2010) UN-Water Global Annual Assessment of Sanitation and Drinking-Water (GLAAS). 102. Retrieved from http://www. who.int/water_sanitation_health/publications/9789241599351/ en/index.html. Accessed 13 Mar 2020
62. Williams LJ (2010) Principal component analysis. Comp Stat 2(August):433-459. https://doi.org/10.1002/wics.101

63. Xiao X, Xi BD, He XS, Zhang H, Li YH, Pu S et al (2019) Redox properties and dechlorination capacities of landfill-derived humic-like acids. In: Environmental pollution, vol 253. https:// doi.org/10.1016/j.envpol.2019.07.044

64. Yang L, Chen W, Zhuang WE, Cheng Q, Li W, Wang H et al (2019) Characterization and bioavailability of rainwater dissolved organic matter at the southeast coast of China using absorption spectroscopy and fluorescence EEM-PARAFAC. Estuar Coast Shelf Sci 21:45-55. https://doi.org/10.1016/j.ecss.2018.11.002

65. Zepp RG, Sheldon WM, Moran MA (2004) Dissolved organic fluorephores in Southeastern US Coastal waters correction method for eliminating Rayleigh and Raman Scattering peaks in excitation-emission matrices. Mar Chem 89(1-4):15-36

66. Zhang W, Zussman E, Yarin AL (2018) Detection of vapor released from sublimating materials encased in porous medium. Int J Heat Mass Transf 118:1357-1372. https://doi.org/10.1016/j. ijheatmasstransfer.2017.11.069

67. Zhang Y, Hu C, Yu T (2015) Photodegradation of chromophoric dissolved organic matters in the water of Lake Dianchi, China. Front Environ Sci Eng 9(4):575-582. https://doi.org/10.1007/ s11783-014-0664-y

Publisher's Note Springer Nature remains neutral with regard to jurisdictional claims in published maps and institutional affiliations. 